\title{
THE PRESIDENTIAL OFFICE AND THE PRESIDENT AS PARTY LEADER
}

\author{
Lester G. Seligman*
}

\section{The President as Political Leader}

A perceptive student of the Presidency, observing the gaps between presidentral policy and their congressional incidence, has stated that "the steady climb of the Presidency in the matter of public policy leadership is one of the patent political truths of the century. This rise has not been accompanied by a corresponding expansion of presidential authority as a party leader." This statement about the gap between these two roles of the President may be taken as not untypical of relationships among other presidential roles.

It has been said many times, and cogently reiterated recently by Louis Brownlow ${ }^{2}$ and Clinton Rossiter, ${ }^{3}$ that the Presidency is a position with many roles. ${ }^{4}$ As testimony to the expansion of presidental roles, Brownlow, writing in 1949, delineated some seven roles, and Rossiter, writing in 1956 , described some nine. It is in terms of the dynamics of these roles that the Presidency can be best understood.

Presidential roles are at once conflicting and complementary. The power of the President in foreign relations has given weight to the President's recommendations as an economic architect, viz., recent policies for the tightening of credit. Recommendations on such domestic matters as school aid are bolstered by claiming their efficacy in our rivalry with Russia. The President's role as communicator with the public adds force to his role in foreign affairs, and vice versa. When the President speaks as a legislative leader his voice is heard more fully because he has the weapons to exert influence over his party.

The weaving of the strengths in the various roles is one of the tests of the political skills of a President. ${ }^{5}$ The President who can skillfully employ influence derived in one role to fortify another zone of presidential competence demonstrates a quality indispensable to broad-gauge leadership.

An expanding office is characterized by role-conflicts. Our recent Presidents have exhibited many such instances. Thus, for example, President Roosevelt's proposals

* B.A. 1939, Ph.D. 1947, University of Chicago. Assistant Professor of Political Science, University of Oregon, since 1953. The author is now engaged in a study of the recruitment of political leadership in our political parties, viewed comparatively in several states, under a grant from the Social Science Research Council. He is also working on a text in the field of political parties.

${ }^{1}$ Malcolas Moos, Politics, Presidents, and Conttails 136, 137 (1952).

2 Louis Brownzow, The President and the Presidency (1949).

${ }^{3}$ Clinton Rossiter, The American Presidency (1956).

- For an analysis of the implication of these for the theory of political leadership, see Seligman, Developments in the Presidency and the Conception of Political Leadership, 20 AM. Soc. Rev. 707 (1955).

"James M. Burns, Roosevelt: The Lion and the Fox (1956) uses "role-taking" as an explanation of Roosevelt's behavior. 
for executive reorganization in 1938 were an outgrowth of an awareness that a burgeoning and uncoordinated executive establishment was incompatible with the President's executive and legislative roles, among others. When Truman discovered that the counsels of some of his lieutenants in the executive establishment were compromising his role as chief executive, he confronted an almost classic role conflict among our chief executives. ${ }^{6}$ President Eisenhower's reluctance to "take on" Senator McCarthy was an attempt to minimize a conflict between his role as chief executive and his role as party leader.

The problem of role-integration in the Presidency is exacerbated by the variety of pressures that impinge upon the office. ${ }^{7}$

For each of the President's multiple roles a matching force in his immediate vicinity wanted him to concentrate on that one role and no other. The McAdoos, with their absorbing interest in California's federal judgeships, were duplicated in other persons whose absorbing interest was the farmer, or the laborer, or the big and little businessmen, or the ground forces, the naval forces, the air forces, the Latin Americans, the English, the Russians, the French, the Chinese, the enemy, the neutral powers, and on and on through all the list of things that make the globe. ${ }^{8}$

This variety of pressures has been more responsible than any other factor for the loose-jointed character of the President's relationships. The President's relationship with his own executive establishment is a struggle of executive program coordination against what Leiper Freeman has called "creeping pluralism." The President finds himself with expanding roles that are little more than opportunities to create the influence necessary to their fulfillment.

Presidents have certain techniques for resolving role-conflicts. ${ }^{10}$ One technique for resolving these jurisdictional conflicts is to erect a system of priorities. Thus, Roosevelt appeared to give greater weight to public approbation than he did to administrative "success." Agencies might be locked in overlapping struggles to the distraction of harassed administrators, yet FDR was inclined to regard this as secondary if the public received the program favorably. Role-conflicts may also be resolved by established "rules of the game" or, to use another phrase, "political etiquettes." The claim of a senator for a favored piece of patronage is such an etiquette that helps the President resolve rival patronage pressures. Role-conflicts may be resolved by tact and diplomacy. Presidential aides often serve as polite buffers. People are shunted aside, are given tactful dismissals and diplomatic "brush offs."

i H Harry S. Truman, Memoirs 227-29 (1955).

7 David B. Truman, The Governamentad Process c. I3 (I95I).

${ }^{8}$ Marriner S. Eccles, Beckoning Frontiers 33 I (x95I).

${ }^{\circ}$ On this point, see the recent analytical summary by $\mathrm{J}$. Leiper Freeman, The Politucal Process; Executnve Bureav: Legislative Comimittee Relations esp. c. 3 (1955).

${ }^{10}$ Recently a colleague and this writer conducted an attitude analysis of expectations of leadership. A list of some fifty presidential role-conflict situations was compiled characteristic of the experiences of our recent Presidents. Some of these role-conflicts were simple ones between two roles. Others were multiple conflicts in which several areas of presidential competence were locked in critical choices. The study is forthcoming. 
Role-segregation is another method. Thus, Eisenhower, to a greater extent than any previous President, has delegated his duties to particular cabinet members and to members of his staff. The President thereby relieves himself of the pressures of one of his roles. Among other familiar techniques that our Presidents have employed are the following: playing off one group against another to mitigate clashing demands of each; "stalling" until the pressure subsides; resolving conflicts by redefining roles; leading a "double life." To sum up, there are more or less institutionalized techniques for preventing or diminishing role-conflicts. ${ }^{11}$ Nonetheless, the dynamics of presidential roles proceed at a faster rate than the techniques for their management.

Role-conflicts are characteristic in the unintegrated system that are presidential relationships. The power of the President rests upon and takes place within certain institutionalized frameworks, but presidential infuence, in contrast to presidential power, is something the President himself must create. Within the circumference of historical expectations of presidential conduct, there are wide areas where the grooves of behavior are ambiguous. In this area, the President is free to carve out for himself, through his perceptions of his role and the practical limits of political consensus, the paths he chooses to follow.

"To get any kind of measure enacted, the President has to build a special coalition for the immediate object in view. Sometimes he can do this by reshuffling the forces within his party. He can also pick up support from among the dissidents in the opposition, or he can appeal directly to the nation in the hope that its groundswells will override all party lines."12 The President's role as a party leader is, thus, at the hub of his other roles.

A salient characteristic of these presidential roles is the extent to which their fulfillment is contingent upon the activities of a staff and a burgeoning Executive Office. ${ }^{13}$ This office has been a product of the expanding roles of the President and an important instrument for their integration. For, to a large measure, the President imparts to his office his particular interpretation of the Presidency. The Presidency today is an increasingly organizational product to which many contribute. The processes we call presidential action are distilled from a myriad of organized activities, formal and informal. We wish to discuss some aspects of the party leadership role in this new organized face of the Presidency.

\section{The Presidential Office and the White House Faction}

The President rises to his position in varying degrees through the channels of a

${ }^{11}$ See L. J. Neiman and James W. Hughes, The Problem of the Concept of Role-A Resurvey of the Literature, 20 Social Forces I4I (1952); Toby, Some Variables in Role-Conflict Analysis, 30 Social Forces 324 (1952); Harold D. Lasswell, Power and Personality c. 2 (1948).

${ }^{12}$ S. Hyman, The American Presidency 53 (1954).

${ }^{13}$ On developments of the Executive Office of the President, see Edward H. Hobds, Behind THE Prestdent (1954); F. M. Marx, The President and his Staff Services (1947); B. P. Nash, Stappino THE Prestdency (National Planning Ass'n Pamphlet No. 80, I952); the symposium of articles edited by F. M. Marx, Federal Executive Reorganization Re-examined: A Symposium, in 40 AM. PoL. Scr. REv. 1124 (1946). 
party organization. He must, at the least, even if he is an "outsider," receive his party's nomination. ${ }^{14}$ He enters the White House bringing with him a party component which he has been chiefly instrumental in fashioning and vice versa. The National Committee is headed by a National Chairman who is his appointee. The staff of the national organization is usually an extension of his nominating and election campaign organizations. He staffs his cabinet and top policy positions with leading figures drawn both from his strong supporters and the rival factions whose support must be won. Taken together with the President's staff and the larger executive establishment, these constitute what may be called the party in the Presidency. It is this presidential party which has gained ascendancy over the legislative branch. It has also served as the cutting edge of a presidential program ${ }^{15}$ and as an important contributor working toward the greater centralization of our parties.

Historically, Andrew Jackson transferred the leadership of the party away from congressional leaders and placed it in the executive. The political nominating conventions were an outgrowth of this assertion of presidential influence over the party structure. Jackson's celebrated "kitchen cabinet" was a principal instrument in effecting that change. For Theodore Roosevelt, Woodrow Wilson, and Franklin D. Roosevelt, the President's inner circle served as the core of the political party in the executive.

With the administration of Franklin D. Roosevelt, this presidential inner circle acquired increased importance. Under a President who was confronted with a broad job of reconstruction in national crisis, the President's inner circle matured as a flexible instrument of political leadership. ${ }^{16}$

Since $x 93^{8}$, the presidential inner circles have been supplemented by a rapidly growing institutionalized staff. New expectations of leadership in domestic areas resulted in a vast expansion of the role of chief executive. In response to expanding administrative agencies, the President needed, in Luther Gulick's phrase, more "functional arms, legs, and eyes." The history and development of presidential reorganization is a subject of another essay in this symposium. The presidential staff, which includes White House staff and the Executive Office of the President, now consists of several thousand people. ${ }^{17}$

The brain trust formed during Franklin D. Roosevelt's governorship was the nucleus of a group later active in preparing the President-to-be for the campaign of I932. Members of the same group continued as presidential intimates after Roosevelt was inaugurated, though many were assigned formal positions in various de-

14 David P. and R. Goldman, Presidential Nominating Patterns (1956).

${ }^{25}$ E. P. Herring, Presidential Leadership 24 (1940).

${ }^{10}$ Samuet Rosenaran, Working witat Roosevelt (I952); Raymond Molex, After Seven Years (I939); Joseph Alsop and R. Kintwer, The Men Around the President (1939); Tugwell, The Preparation of a President, I W. PoL. Q. I3I (1948).

${ }^{17}$ For the developments in White House staff organization, see Mr. Truman's White House, Fortune, Feb. 1952, p. 74; Murphy, Eisenhower's White Housse, Fortune, July 1953, p. 75; Neustadt, Presidency and Legislation, 48 AMr. PoL. Scr. Rev. 641 (1954). 
partments. In time, members of this presidential faction occupied positions in many of the departments and, particularly, the new administrative agencies. ${ }^{18}$

From the first, this group was in a restless harmony with James Farley and the professional party politicians in Congress and on the state and local levels. In the early years of the New Deal, the brain trust-politician relationship was somehow maintained. With the Roosevelt second term, however, a new group, those historically labeled the "New Dealers," took their places as the President's closest advisers. This "group" included Ben Cohen, Tom Corcoran, the late Justice Jackson, and Harold Ickes, and many of the more intellectual additions to the federal bureaucracy. It was allegedly while this group was influential that Roosevelt shifted to the "left."

Opposition from Congress and party officials rose to new levels against this group. Referring to these presidential aides, James Farley stated: "White House confidence in politics and policies went to a small band of zealots, who mocked at party loyalty and knew no devotion except unswerving obedience to their leader."10 The matter may be said to have come to a head in the Supreme Court fight, a bill which critically divided Roosevelt's party in Congress and alienated some of Roosevelt's strong supporters. The cleavage was deepened by the ill-fated attempt by Roosevelt to purge congressional and senatorial candidates in the bi-elections of 1938. This was a move allegedly counseled by this group and bitterly opposed by Farley and the party professionals. The latter regarded it as a bold attempt to create a personal party and a rude violation of political orthodoxy. ${ }^{20}$

The $193^{8}$ purge attempt was an effort on the part of FDR to shape the Democratic Party in Congress in the image fashioned by him and the presidential faction. By the election of 1940, the lines of cleavage were clearly drawn. While the manifest issue appeared to be the legitimacy of a third term, the latent issue was the battle between two centers of influence, the White House group now headed by Harry Hopkins and the party professionals headed by Farley. ${ }^{21}$ The issue was thus truly whether the presidential party in the White House would have the executive powers plus Roosevelt's enormous popularity to reshape the party organization.

The onset of the war brought a truce, but the issue arose again in the election of 1944. The battle over the vice-presidential candidates, Wallace and Truman, in which Roosevelt played an evasive role, was interpreted as a retreat before the mounting opposition to the New Dealers. With the mounting opposition in Congress, Roosevelt became so discouraged over the prospect for reshaping the Democratic Party that in 1943, he entertained the idea of joining with Wendell Willkie to create a new liberal party. ${ }^{22}$ Willkie's untimely death prevented any further development. It was clear after Roosevelt's death that the Democratic Party had a new

\footnotetext{
18 C. Michelson, The Ghosts Talks 52 f. (I944).

10 JaMies Farlex, JiM F FrLey's Story 68 (1948).

$20 \mathrm{Id}$. at 147 .

${ }^{21}$ Robert Sherwood, Roosevelt and Hopkins i76-78 (1948).

22 Rosenman, op. cit. supra note 16 , at 386 .
} 
wing-the New Dealers. These regarded themselves as the legatees of the New Deal as represented by the Roosevelt program of $1935-38$.

The preceding are only some highlights illustrative of the tension between the presidential party and the party in Congress and the party on state and local levels in the Roosevelt years. The tension was repeated with Truman. When Truman ran on the Fair Deal program of I948, he was essentially supported by his presidential faction. It was they who fashioned the legislative program on which he took his stand. It was they who urged him to fight when the leading party professionals were abandoning him for a vote getter like Eisenhower.

In the Eisenhower administration, the role of the White House faction has made itself strongly felt in party matters. Under the President's chief of staff, Sherman Adams, party matters have come under close White House supervision. It is evident that the split that prevailed in the Republican Party in 1952 between Taft supporters and the Eisenhower supporters has continued. As long as Taft was alive, this right wing was kept in reasonable harmony with the President. The period of McCarthy's ascendancy marked a low point of Mr. Eisenhower's influence in this party group.

In the elections in I954, the President departed from his early pledge to keep hands off the election and intervened on behalf of Republican candidates in senatorial and congressional races. In the elections in November, the President's hand was more strongly asserted on behalf of certain congressional and senatorial candidacies. ${ }^{23}$

Mr. Eisenhower would appear to be in a phase familiar to his two Democratic predecessors. We know now (thanks to a recent account ${ }^{24}$ ) that the President had contemplated the abandonment of the Republican Party to embark upon a program of refashioning it in the image of the presidential program. The dynamic conservatism with which Mr. Eisenhower is identified has been fashioned and intellectualized by the White House staff-notably its economists, Gabriel Hauge and Arthur F. Burns. ${ }^{25}$ It has borrowed many a leaf from the New Deal policies of social welfare and compensatory fiscal policy, coupled with a more cordial attitude toward business interests.

Only a brief word is possible at this point about the other agencies of the Executive Office of the President. Historically, in this complex, the Bureau of the Budget, OWMR, the Economic Adviser, and latterly, the National Security Council, have played key roles. Their utility as devices for coordination does not concern us, but their contribution toward mobilizing technical assistance for the President is a matter of significance. These are agencies that operate in a political context and are not immune from the tactical considerations that guide the President. Their party significance lies perhaps in that they have become essential to the substantive pro-

\footnotetext{
${ }^{23}$ Notably in the senatorial races in Oregon and Washington, though differently in Wisconsin.

24 Robert J. Donovan, Eisenhower: The Inside Story I5I-53 (I955).

${ }^{25}$ It is significant that Mr. Arthur Larson, Undersecretary of Labor and the author of the widely noted book on Eisenhower conservatism, has been pulled into the White House Staff.
} 
gram and administrative impact of the presidential party we have described. ${ }^{26}$ Collectively, these new agencies represent an effort to raise to the highest level broad policy considerations, ${ }^{27}$ where the President may use his influence over Congress, his party, or the people as a whole. "It is the power that lodges at low points in the executive hierarchy that is hardest to bring to light and hold effectively accountable"28 and where interest groups may enjoy their widest play.

\section{The President and the Decentralized Party}

Not long ago, the delineation of our party system followed a familiar model. ${ }^{20}$ The model was described in the following terms. The base of power in our parties was in the states and localities. On this level, the political party was a political machine organized hierarchically with a boss at its apex. The President and national party apparatus played subordinate roles.

The changes of the past two decades have threatened this model with obsolescence. There is a closure of the traditional gaps among state, local, and federal governments. In a myriad of ways, some controlled and others uncontrolled, a creeping nationalization has been taking place. The dynamic balance between state, local, and federal government is being constantly altered. In this process, presidential action has been both cause and effect. The impact of executive sponsored statutes and executive administrative decisions of recent decades in making local matters of national concern, and vice versa, is too obvious to repeat.

Inevitably, this has affected party structure and functioning in the states and federal government. ${ }^{30}$

Between the state and local party organization and federal government is a close relationship of interdependence. In the organization and spirit of their politics, the states vary markedly. Their oddities and variations may be accounted for in part by the fact that they are members of a federal system. The impact of national policies and parties powerfully influence the form and behavior of state political systems. The manner in which that impact strikes different states, differently constituted and situated contributes to the variation in organization and conduct of state politics. ${ }^{31}$

One index of change of the presidential role in state and local politics is reflected in the changes in urban political machines. The decline of the large urban machines is a symptom of the social changes we have indicated. ${ }^{32}$ New Deal legislation was

${ }^{20}$ Maass, In Accord With the Program of the President, in C. J. FrIedrich AND J. K. Galmpaith (Eds.), 4 Public Policy (Yearbook of the Graduate School of Public Administration, Harvard University) 77 (1953); Herman Somers, Presidential Agency (1951); W. Cikins, The Council of Economic Advisers, in 4 Public Policy, op. cit. supra, at 94; Hood, Reorganizing the Council of Economic Advisers, 69 PoL. Scr. Q. 412 (1954).

${ }^{27}$ Seligman, Presidential Leadership: The Inner Circle and Institutionalization, I8 J. Pourncs 4 Io (1956).

${ }_{28}^{8}$ D. K. Price, The Presidency, in Strengthening American Political Institutions 108 (1949).

29 E. E. Schattschneider, Party Government (1942).

${ }^{30}$ David B. Truman, Federalism and the Party System, in A. W. Macmahon (Ed.), Federalism, MATURe and EMERgent (1955).

31 V. O. Key, American State Politics 19-20 (1956).

${ }^{32}$ It would be premature to proclaim that the boss is extinct, for there is fresh evidence that new, though limited, bosses are developing in some of our major metropolitan areas. 
responsible, both directly and indirectly, for undermining the position of the urban machines. Voters have been liberated from their dependence upon paternalistic local leaders as new legislation and federal administrative agencies have moved into the areas impinging most closely on human welfare. ${ }^{33}$ What is evident is that state and local party organization have been weakened. ${ }^{34}$ Interest groups, ardent amateurs in political clubs, and public relations experts are tending to fill the vacuum of political leadership and organization. Personal organizations created by candidates are increasingly supplanting party organizations. Associated with this development, a growing number of our national legislators are representatives of constituents with social and economic interests that are more national and less sectional in scope, viae: civil liberties, labor policy, education, social security. ${ }^{35}$ It may be suggested that becalise of this, our legislators' involvement with a presidential program has increased. However, in those states where economies are less complex and major interests are few, involvement with a presidential program is less, and White House pressure for party voting is more precarious.

Governors and mayors rank high in influence within state and national party organizations. ${ }^{36}$ While local orientations are deeply imbedded, these leaders, by and large, often function more symbiotically with the President than do the national legislators. The increased dependency of state governments and, particularly, metropolitan areas, on federal largesse and administrative support, provides a strong link of party influence.

The President has traditionally employed the techniques of persuasion, patronage and "dealing" to build a congressional majority. Since Franklin D. Roosevelt, the White House staff and informal advisers have worked on the Hill to guide legislation. ${ }^{37}$ When necessary, the President could tap his alliances with state and local party organizations to apply pressure to recalcitrant congressmen and senators. This technique was used largely in those states where a tight hierarchical party organization prevailed.

A significant technique employed by the President is the appeal to the public as a whole. So fluid has been our party discipline and identification that, paradoxically, the appeal by the President as a national leader is a major technique for party discipline in Congress and in the states. In recent years, with the mounting evidence of economic and cultural nationalization, this leadership technique has special meaning. It is a way whereby the President may exploit national consensus, sharpened by cold war tensions, to offset the particularism of legislators, while

${ }^{33}$ Truman, op. cit. supra note 7 , at 270-87 (I95I).

34 M. Meyerson and E. C. Banfield, Politics, Planning and the Public Interest c. il (i955); C. R. Adrian, Governing Urban America cc. 5, 6 (i955).

35 $\mathrm{KEY}$, op. cit. supra note $3 \mathrm{I}$, at 26 .

${ }^{30}$ Moos, New Light on the Nominating Process, in Research Frontiers in Politics and GovernMIENT 148 85 (1955).

${ }^{37}$ Mr. Eisenhower employs a principal staff assistant, General W. Persons, and his staff to maintain active and regular liaison with Congress. 
weakened party organization and party identifications by the electorate ${ }^{38}$ can erect fewer defenses against it.

The President “Above" Party

One of the dilemmas of the Presidency is that it is a position with two mandates, one from a political party and another from the public-at-large. The fact that each mandate is ambiguous creates at once leadership opportunities and complications.

The President's political party is at least nominally committed to mobilizing its adherents on his behalf. The presidential electorate is always broader than the steadfast party supporters. $^{39}$ In recent years, the presidential electorate has become more fluid. ${ }^{40}$ The tides in voting behavior from Roosevelt through Eisenhower have been variously analyzed. The social mobility in the postwar era to which we have previously alluded has done much to dilute previous long standing group identifications.

Our recent Presidents, armed with newer weapons of mass communication, have relied on methods that bypass party structures and appeal directly to the electorate. All of our recent Presidents have found these methods efficacious. It is no exaggeration to say that the President's most influential role and skill has become that of a public communicator. ${ }^{41}$ The technological revolution in the mass media-press, radio, and television-coupled with the sophistication and professionalization of insights into mass persuasion, have made possible an intensified relationship between the President and the public. The organized character of this relationship is one of the notable features of our politics. "President Roosevelt seems to have been the first President ... to establish and utilize systematically and continuously an elaborate organization designed to gauge public sentiment and world public opinion." ${ }^{2}$ Because these set a pattern that other Presidents followed, they are worthy of greater attention.

Like no President before him, Franklin D. Roosevelt developed a regular relationship with the press. Sensitive to public opinion and conscious that a political leader's strength is dependent upon his interaction with the public, Roosevelt virtually "revolutionized the government relationship with the Press." 3 The regular give-and-take press conference was among his most important innovations. The calculated timing of publicity, the planned "leak," and "straw in the wind" device, were all methods which Roosevelt artfully employed.44

${ }^{38}$ See S. Lubell, The Revolt of the Moderates (1955).

30 "Prior to World War I presidential candidates usually received about five per cent morc votes than congressional candidates; since World War I the difference has risen to about twelve per cent." Moos, supra note 36 , at $\mathbf{7}$.

40 A. Campbell, D. Guerin, and W. Milleter, The Voter Decides (1953); S. Ludell, The Future of American Politics (195I), and The Revolt of the Moderates, op. cit. supra note 38.

${ }^{41}$ W. F. Binkley, The President and Congress 248 (1947).

${ }^{2}$ See Brownlow's discussion, op. cit. supra note 2, c. 4.

${ }^{43}$ Rosten, Political Leadership and the Press, in Essays in Honor of Charles E. Merruas 94 (1941).

"Readers would find illuminating FDR's discussion of public relations with his cabinet. See Proceedings of the National Emergency Councir, 1933-1935 (U. S. Archives). 
The new press relationship created a new middleman technican between the President and the public, the White House Press Secretary. "His unhappy job is trying to keep the public, represented by the reporters and photographers, and the President pacified and pleased. The right kind of twenty-four hour publicity on everything a President does has become requisite to his political survival."45

The Press Secretary and his staff perform a variety of tasks for the President. His strategic position and intimacy with the President give his job a free-wheeling character. He is an important "buffer" for the President, as well as an important liaison agent in the array of presidential relationships. His management of news dissemination, institutionalized now in the regular press conference and public addresses, give him an important voice in the timing and often in the content of messages. Because he thinks in terms of "news" and of the President's interests, no President can afford to ignore his counsel or fail to exploit his competence.

In the Eisenhower administration, James Hagerty, the Press Secretary, has emerged as one of the key figures. He regularly attends cabinet meetings and plays a leading role in the making of many political decisions. Some observers contend that he has become a gatekeeper to all important communications that flow not only from the White House, but from cabinet departments as well. Illustrative of Mr. Hagerty's influence is his role in the two crises attendant upon the President's illness. At a time of public anxiety, he became, in effect, the controlling voice of the administration. ${ }^{46}$

A measure of the personal identification between the President and the public is given us by the volume of mail addressed to the President. Franklin D. Roosevelt wanted the public to write him. "Throughout the Roosevelt administration every day brought an average of more than five thousand letters a day.... In times of great crisis, it would frequently be as much as twenty-five thousand a day for a week." 47 Roosevelt had White House mail carefully tabulated "as an indicator of what issues were most on the public mind." ${ }^{8}$ In several fireside chats, he encouraged mail barrages against Congress at critical moments in decisions on legislation. ${ }^{40}$ As a party weapon, this tactic was employed to light fires under congressional, state, and local party leaders, to assert both his leadership of his party and his leadership over party. The communication techniques that FDR refined and so dramatically employed are institutionalized now by virtue of their continuation by Truman and Eisenhower.

The President's personality has been split from his official acts. As a result, greater expectations of presidential leadership have been stimulated.

James Reston recently reported $:^{50}$

ss Merriman Smith, A President Is Many Men 86 ff. (1948).

${ }^{4}$ Deakin, Hagerty: Voice Behind the Throne, New Republic, Aug. 27, 1956, p. 7; Ike's Man fim Hagerty, Newsweek, Aug. 6, 1956, p. 23.

${ }^{47}$ Brownlow, op. cit. supra note 2 , at 70 .

${ }^{48}$ Sussman, FDR and the White House Mail, 20 PuB. Oprnion Q. 9 (1956).

${ }^{40}$ Rosenman, op. cit. stupra note 16 , at $170,428 .{ }^{50} \mathrm{~N}$. Y. Times, Sept. II, 1955, $\$ 4$, p. 8E, col. 5. 
The popularity of President Eisenhower has got beyond the bounds of reasonable calculation and will have to be put down as a national phenomenon, like baseball. . . . Very much against his will, the President is suddenly being presented as the answer and solution to everything-war, juvenile delinquency, the decline in farm prices, parental irresponsibility, the division of Europe and Germany, polio, death on the highways, the school shortage and the rest. When the Republican state chairmen met here this week, they went over all these things and came to the same conclusion about everything. Ike was the answer.

This technique has served to make the President a person "above" party. However, such elevation pushes party responsibility farther beyond reach. If the Presidency relies too heavily on popular appeal, then party organization necessarily becomes subordinated and weakened. We see, then, the trend toward the "personalization" of the Presidency as a threat to party organization.

This new dimension of presidential influence has opened a direct channel to party adherents in the electorate that circumvents party organization. The middleman of party organization is being displaced by the direct communication possible between the President and informal opinion leaders in the community who hold no party posts. Frank Hague, in his days of power, reputedly once said that "Franklin D. Roosevelt was the best precinct captain that he had." Hague's remark pithily illustrates the point. The President can, through mass appeal, awaken and foster new groups of party activists who oppose existing party organization.

A recent analysis of the Republican Party in Michigan describes the factional conflict that has served to weaken the party. ${ }^{51}$ The factional splits revolve around a new "self-starting" element that has arisen out of the intense "followership" of President Eisenhower. These Eisenhower zealots challenged the existing organization and are still locked in struggle with it.

Perhaps the most striking paradox of this new dimension of presidential influence is that it has grown simultaneously with the President's efforts and success in crystallizing national issues for public debate. There is a fine line, easily traverscd, between public education on issues and demagogic appeals. The power of the mass media makes possible the projection of many types of address. Which aspect of a message is most salient is partly a matter of audience predisposition and its environment, and the purposes of the communicator. There are serious dangers when, through mass manipulation, false expectations of leadership are generated.

We have attempted to place the President's party leadership role in the context of its dynamic relationship to the President's other roles. We have considered the growth in presidential influence as it has been augmented by the presidential party in the executive, changes in state and local party organizations, and through enhanced public response.

${ }^{51}$ Norton-Taylor, What's Wrong With Michigan, Fortune, Dec. 1955, p. 142. 